\title{
Effects of Displacement Velocity on Rock Fracture Shear Strengths under Large Confinements
}

\author{
Matsee Kleepmek ${ }^{1}$, Supattra Khamrat ${ }^{1} \&$ Kittitep Fuenkajorn ${ }^{1}$ \\ ${ }^{1}$ Geomechanics Research Unit, Institute of Engineering, Suranaree University of Technology, Thailand \\ Correspondence: Kittitep Fuenkajorn, Geomechanics Research Unit, Institute of Engineering, Suranaree \\ University of Technology, Thailand. E-mail: kittitep@sut.ac.th
}

Received: January 19, 2016

Accepted: February 11, 2016

Online Published: April 8, 2016

doi:10.5539/esr.v5n2p32

URL: http://dx.doi.org/10.5539/esr.v5n2p32

\begin{abstract}
Triaxial shear tests are performed to assess the effects of displacement velocity and confining pressure on shear strengths and dilations of tension-induced fractures and smooth saw-cut surfaces prepared in granite, sandstone and marl specimens. A polyaxial load frame is used to apply confining pressures between 1 and $18 \mathrm{MPa}$ with displacement velocities ranging from $1.15 \times 10^{-5}$ to $1.15 \times 10^{-2} \mathrm{~mm} / \mathrm{s}$. The results indicate that the shearing resistances of smooth saw-cut surfaces tend to be independent of the displacement velocity and confining pressure. Under each confinement the peak and residual shear strengths and dilation rates of rough fractures increase with displacement velocities. The sheared-off areas increase when the confining pressure increases, and the displacement rate decreases. The velocity-dependent shear strengths tend to act more under high confining pressures for the rough fractures in strong rock (granite) than for the smoother fractures in weaker rocks (sandstone and marl). An empirical criterion that explicitly incorporates the effects of shear velocity is proposed to describe the peak and residual shear strengths. The criterion fits well to the test results for the three tested rocks.
\end{abstract}

Keywords: displacement velocity, shear strength, dilation, rock fracture, Barton criterion

\section{Introduction}

Understanding of the frictional behavior of rock fractures is important for the prediction of natural geologic hazards (e.g., fault movements and landslides), and for the stability evaluation of geo-engineering structures (e.g., tunnels, mine openings, foundations and waste repositories). The frictional resistance of rock fracture is conventionally determined by the direct shear testing (e.g., ASTM D5607-08) which provides the peak and residual fracture shear strengths under constant normal load (CNL) or under constant normal stiffness (CNS) (Usefzadeh et al., 2013; Shrivastava \& Rao, 2015). The direct shear test configurations have some disadvantages. The magnitudes of the applied normal stress are limited by the uniaxial compressive strength of the rock, and the fractures are sheared under unconfined conditions. Their results may not truly represent the friction behavior and movement of the fractures at great depth where the fractures are under high normal stresses and confinements. The triaxial shear test method (Barton, 1976; Brady \& Brown, 2006; Jaeger et al., 2007; Li et al., 2012) has therefore been developed to simulate the frictional resistance of rock fractures under confinements. The cylindrical rock core containing an inclined fracture or weakness plane can be axially loaded in a triaxial pressure cell with a wide range of applied confining pressures. The normal stress at which the shear strengths are measured can be controlled by the applied axial stress and confining pressures. Barton (1976) states that under higher confining pressures the behavior of rock ceases to be brittle as the brittle-ductile transition is reached. The Mohr envelopes describing failure of intact rock eventually reach a point of no gradient on crossing a certain line, defined as the critical state line. This critical state is associated with a critical effective confining pressure for each rock. It appears that the dilation normally associated with the shearing of non-planar joints and faults may be completely suppressed if the applied stress reaches the level of the critical effective confining pressure. The triaxial shear test results obtained by Li et al. (2012) suggest that the back-predicted joint compressive strength (JCS) from triaxial shear tests under high confining pressures is larger than the rock uniaxial compressive strength which might be attributed to the size effect. Barton (1976) and Barton \& Chouby (1977) propose a shear strength criterion for the fractures under high confining stresses. They replace the joint compressive strength (JCS) parameter by the difference between the maximum and minimum principal stresses at failure of 
intact rock $\left(\sigma_{1}-\sigma_{3}\right)$. The criterion agrees well with the shear test results of fractures in Weber sandstone. Results from true triaxial shear testing obtained by Kapang et al. (2013) also suggest that the confining stress parallel to the strike of the fracture plane can also cause localized stress concentration and dilation of the asperities on the fracture wall, and hence weaken the rock asperities and reduce the peak shear strengths of the fracture.

Different displacement velocities may impose different behavior to the shearing resistance of rock fractures. Crawford \& Curran (1981) state that the frictional resistance of rock joints depends on the rate of shear displacement. For hard rocks, the resistance decreases with increasing shear displacement rates greater than a variable critical velocity. For soft rocks, the resistance increases with increasing shear velocity, up to a critical shear displacement rate, and thereafter remains essentially constant. Laboratory test results by Curran and Leong (1983) suggest that the fracture shear strengths are sensitive to a certain range of shear velocities. Above and below this range the fracture shear strengths are independent of the shear velocity. Li et al. (2012) perform cyclic shear tests (with shear velocities ranging from 0.5 to $50 \mathrm{~mm} /$ minute) on artificial rock fractures and conclude that the residual shear strength increases with displacement velocity. The effect of the shear velocity on the peak stress remains inconclusive due to the complex variability of the asperities.

Relevant factors influencing the shearing behavior of rock fractures have been identified and studied. These include, for example, scale effect (Bandis et al., 1981; Fardin et al., 2001; Johansson \& Stille, 2014), thermal loading (Stesky et al., 1974; Lockner et al., 1986; Mitchell et al., 2013), cyclic loading (Lee et al., 2001; Kamonphet et al., 2015; Jafari et al., 2003), and water pressure (Stesky, 1978; Yeo et al., 1998). Several criteria and models have been proposed to describe the rock fracture shear strength under these conditions (e.g., Grasselli \& Egger, 2003; Asadollahi \& Tonon, 2010; Barton, 2013; Usefzadeh et al., 2013). The effects of confining pressure on the shearing behavior of fractures however have rarely been addressed and experimentally investigated. In particular a strength criterion that can describe the shearing resistance of rock fractures under high confining pressures with varying displacement velocities has never been developed.

The objective of this study is to develop a fracture shear strength criterion that can explicitly incorporate the effects of confining pressure and displacement velocity. The task involves performing triaxial shear tests to obtain the strengths and dilations of rock fractures under confining pressures up to $18 \mathrm{MPa}$. Tension-induced fractures and smooth saw-cut surfaces are prepared in granite, marl and sandstone specimens. Under each confinement the fractures are sheared with constant displacement velocities ranging from $1.15 \times 10^{-2}$ to $1.15 \times 10^{-5}$ $\mathrm{mm} / \mathrm{s}$. The joint roughness coefficients (JRC) are determined prior to and after shearing.

\section{Rock Samples}

The rock samples used in this study are Tak granite, Phra Wihan sandstone and Lopburi marl. The granite is a felsic and phaneritic rock, comprising $40 \%$ plagioclase (with grain sizes of $0.5-1 \mathrm{~mm}), 30 \%$ quartz $(2-5 \mathrm{~mm}), 5 \%$ orthoclase (3-5 mm), 3\% amphibole (1-2 mm), and 2\% biotite (1-2 mm) (Mahawat et al., 1990). The granite batholith is exposed in the northwest of Thailand where there are several active faults and seismic activities (Fenton et al., 2003). The sandstone is fine-grained comprising $72 \%$ quartz $(0.2-0.8 \mathrm{~mm}), 20 \%$ feldspar $(0.1-0.8$ $\mathrm{mm}), 3 \%$ mica $(0.1-0.3 \mathrm{~mm}), 3 \%$ rock fragment $(0.5-2 \mathrm{~mm})$, and $2 \%$ other $\quad(0.5-1 \mathrm{~mm})$ (Boonsener \& Sonpiron, 1997). It largely is exposed in the northeast of Thailand where it is the host rock to several tunnel roadways and railways, power plants and dam foundations. The calcitic marl comprises mainly of calcite (Bunopas, 1992). Several quarries in the central of the country produce and export this ornamental stone.

The basic mechanical properties of the rocks are determined by performing uniaxial and triaxial compressive strength tests. The test procedure and calculation methods are in accordance with the ASTM (D7012-07) standard practice. Based on the classification suggested by the International Society for Rock Mechanics (ISRM - Brown, 1981) the granite, sandstone and marl are classified as very strong, medium strong and strong rocks. Table 1 summarizes the results of the mechanical testing.

For the triaxial shear testing the specimens are prepared to obtain rectangular blocks with nominal dimensions of $50 \times 50 \times 87 \mathrm{~mm}^{3}$. Two types of fractures are artificially made in the laboratory: tension-induced fractures and smooth saw-cut surfaces. They have nominal areas of $50 \times 100 \mathrm{~mm}^{2}$. The normal to the fracture plane makes an angle $(\beta)$ of $59.1^{\circ}$ with the specimen vertical axis. The tension-induced fractures are clean and well mated. The asperity amplitudes are measured from the laser-scanned profiles along the shear direction. The readings are made to the nearest $0.01 \mathrm{~mm}$. Figure 1 shows examples of laser scanned images for the three rock types. The maximum amplitudes are used to determine the joint roughness coefficients (JRC) of each fracture based on the Barton's chart (Barton, 1982). Each rock type tends to show a consistent degree of fracture roughness. The means and standard deviations of the JRC's are $13 \pm 1.0,10 \pm 0.5$ and $11 \pm 0.5$ for the granite, sandstone and marl, 
respectively. All fractures show both first and second order asperities.

It is recognized that there have been several systems and approaches proposed to describe the rock fracture roughness (e.g., Lee et al., 1990; Odling, 1994; Belem et al., 2000; Tang et al., 2012). The JRC is used here primarily because it is relatively simple and quick to determine from the two-dimensional fracture profile along the shear direction. It has been widely applied in the analyses of fracture and fault shear strengths.

Table 1. Mechanical properties of rock samples

\begin{tabular}{|c|c|c|c|c|c|c|}
\hline \multirow{3}{*}{ Rock Types } & \multirow{3}{*}{\multicolumn{2}{|c|}{$\begin{array}{l}\text { Density } \\
(\mathrm{g} / \mathrm{cc})\end{array}$}} & \multirow{3}{*}{$\begin{array}{l}\text { Uniaxial } \\
\text { Compressive } \\
\text { Strength, } \quad \sigma_{\mathrm{c}} \\
(\mathrm{MPa})\end{array}$} & \multirow{3}{*}{$\begin{array}{l}\text { IRSM Classifiacation } \\
\text { (Brown, 1981) }\end{array}$} & \multicolumn{2}{|c|}{ Triaxial Compressive Strengths } \\
\hline & & & & & \multirow[t]{2}{*}{$\overline{\mathrm{c}(\mathrm{MPa})}$} & \multirow[t]{2}{*}{$\phi_{\mathrm{i}}$ (degrees) } \\
\hline & & & & & & \\
\hline \multirow[t]{2}{*}{ Tak Granite } & 2.65 & \pm & \multirow[t]{2}{*}{$118 \pm 5.2$} & \multirow[t]{2}{*}{ Very Strong } & \multirow[t]{2}{*}{17.2} & \multirow[t]{2}{*}{58} \\
\hline & 0.18 & & & & & \\
\hline Wihan & 2.21 & \pm & \multirow[t]{2}{*}{$48.0 \pm 11.0$} & Medium Strong & \multirow[t]{2}{*}{10.0} & \multirow[t]{2}{*}{46} \\
\hline Sandstone & 0.25 & & & & & \\
\hline \multirow[t]{2}{*}{ Lopburi Marl } & 2.35 & \multirow[t]{2}{*}{ \pm} & \multirow[t]{2}{*}{$53.0 \pm 2.5$} & \multirow[t]{2}{*}{ Strong } & \multirow[t]{2}{*}{10.4} & \multirow[t]{2}{*}{43} \\
\hline & 0.13 & & & & & \\
\hline
\end{tabular}
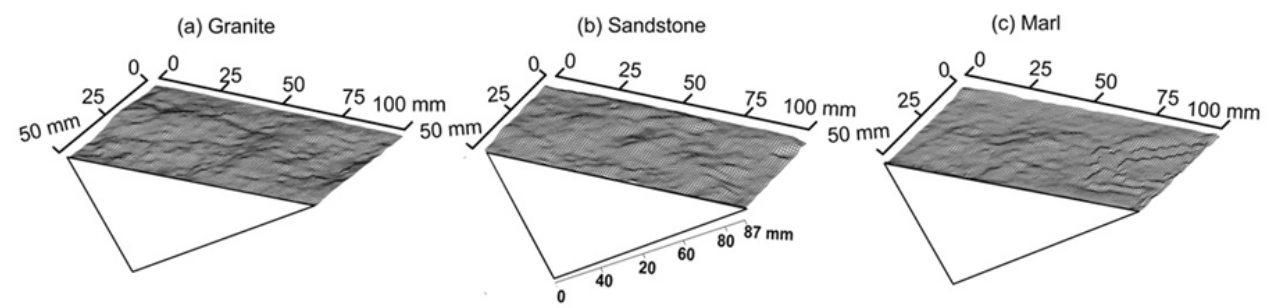

Figure 1. Some fracture images obtained from laser scanning for granite (a), sandstone (b) and marl (c)

\section{Test Apparatus and Method}

A polyaxial load frame (Fuenkajorn \& Kenkhunthod, 2010) is used to apply constant and uniform lateral stresses (confining pressures, $\sigma_{2}=\sigma_{3}$ ) and vertical (axial $-\sigma_{1}$ ) stress to the block specimen. Figure 2 shows the directions of the applied stresses with respect to fracture orientation. The confining pressures are maintained constant at 1 , 3, 7, 12 and $18 \mathrm{MPa}$ for tension-induced fractures, and at 1,7 and $12 \mathrm{MPa}$ for smooth saw-cut surfaces. They are applied by using four cantilever beams arranged in mutually perpendicular directions on the polyaxial load frame. The axial stress is applied under constant displacement rates varying from $10^{-5}$ to $10^{-2} \mathrm{~mm} / \mathrm{s}$ using a 100 -ton hydraulic cylinder. During loading the pressure of the hydraulic cylinder is monitored to calculate the variations of the axial stress. The lateral displacements of the fracture are obtained by monitoring the vertical movement of the cantilever beams.

The specimen is first loaded under hydrostatic stress equivalent to the selected confining pressure. Neoprene sheets are used to minimize the friction at the interfaces between the loading platen and the rock surface. The peak and residual shear strengths are recorded. The test is terminated when a total vertical displacement of $5 \mathrm{~mm}$ is reached. After shearing the fractures are examined, laser-scanned and photographed. The frictional resistance at the interfaces between the loading platens and the lateral neoprene sheets are determined by vertically loading an intact specimen with the same dimensions while the constant lateral stresses parallel to the fracture are applied. The results are shown in Figure 3. They are used to correct the magnitude of the axial stress $\left(\sigma_{1}\right)$ under its corresponding lateral stress $\left(\sigma_{3}\right)$ during the fracture shearing tests.

The shear stress $(\tau)$ and its corresponding normal stress $\left(\sigma_{\mathrm{n}}\right)$ on the fracture can be determined from the applied principal stresses $\left(\sigma_{1}\right.$ and $\left.\sigma_{3}\right)$ as follows (Jaeger et al., 2007; Barton, 2013):

$$
\begin{gathered}
\tau=1 / 2\left(\sigma_{l}-\sigma_{3}\right) \cdot \sin 2 \beta \\
\sigma_{n}=1 / 2\left(\sigma_{l}+\sigma_{3}\right)+1 / 2\left(\sigma_{1}-\sigma_{3}\right) \cdot \cos 2 \beta
\end{gathered}
$$

where $\beta$ is the angle between $\sigma_{1}$ and $\sigma_{n}$ axes. The shear and normal (dilation) displacements $\left(\mathrm{d}_{\mathrm{s}}\right.$ and $\left.\mathrm{d}_{\mathrm{n}}\right)$ can also 
be calculated from the vertical and lateral displacements $\left(\mathrm{d}_{1}\right.$ and $\left.\mathrm{d}_{3}\right)$ as:



Figure 2. Directions of applied stresses by polyaxial load frame, with respect to the fracture orientation

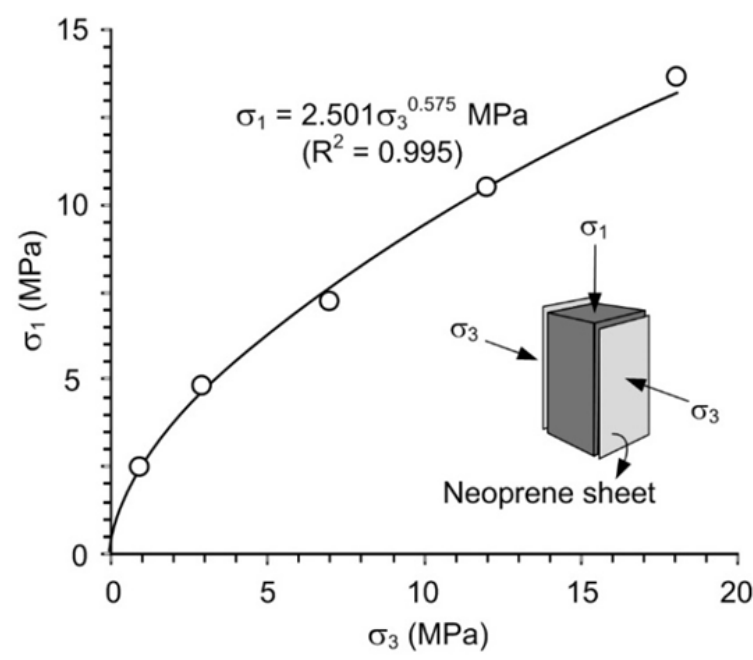

Figure 3. Axial resistance between loading platens and neophrene sheets induced by lateral stress $\left(\sigma_{3}\right)$

where $d_{3, m}$ is the total lateral displacement measured during the test, and $d_{3, c}$ are the calculated lateral displacement induced by the vertical displacement on the incline fracture plane. Using Equation (3) the shear displacement velocities $\left(\dot{d}_{\mathrm{s}}\right)$ that are equivalent to the applied axial displacement velocities $\left(\dot{d}_{1}\right)$ of $10^{-5}, 10^{-4}$, $10^{-3}$ and $10^{-2} \mathrm{~mm} / \mathrm{s}$ are calculated as $1.15 \times 10^{-5}, 1.15 \times 10^{-4}, 1.15 \times 10^{-3}$ and $1.15 \times 10^{-2} \mathrm{~mm} / \mathrm{s}$.

\section{Results of Tension-Induced Fractures}

The shear stress-displacement $\left(\tau-d_{s}\right)$ curves obtained under all displacement velocities are shown in Figure 4 . For all rock types the peak stresses are reached within $2 \mathrm{~mm}$ of shearing. The residual stresses tend to remain constant up to 5 $\mathrm{mm}$ of the displacement. Under each confining stress $\left(\sigma_{3}\right)$, the differences between the peak and residual stresses notably reduced when the fractures are subjected to lower shear velocities. These differences tend to be smaller for fractures with lower JRC values (marl and sandstone) as compared to those with higher JRC values (granite). The major principal stresses for the peak $\left(\sigma_{1, \mathrm{P}}\right)$ and residual $\left(\sigma_{1, \mathrm{R}}\right)$ increase with displacement velocities (Figure 5).

The velocity-dependent shear strength appears for all confining stresses. It tends to act more for the fractures in granite (with high JRC and strength) than in sandstone and marl (with lower JRC's and strengths). This is suggested by a larger separation of the major principal stresses under different displacement velocities found in granite as compared to 
those in sandstone and marl. Using Equations (1) and (2) the peak and residual shear strengths and their corresponding normal stresses can be calculated. The shear and normal (dilation) displacements of the tested fractures can be calculated using Equations (3) and (4). Figure 6 shows the results for $\sigma_{3}=1$ and $18 \mathrm{MPa}$ in the forms of $\mathrm{d}_{\mathrm{n}}-\mathrm{d}_{\mathrm{s}}$ diagrams The dilations measured prior to and after the peak stresses notably decrease with the displacement velocities. The dilations tend to increase with the displacement until the peak stresses are reached, and remain constant in the residual region. This agrees reasonably with the constant residual shear stresses observed during
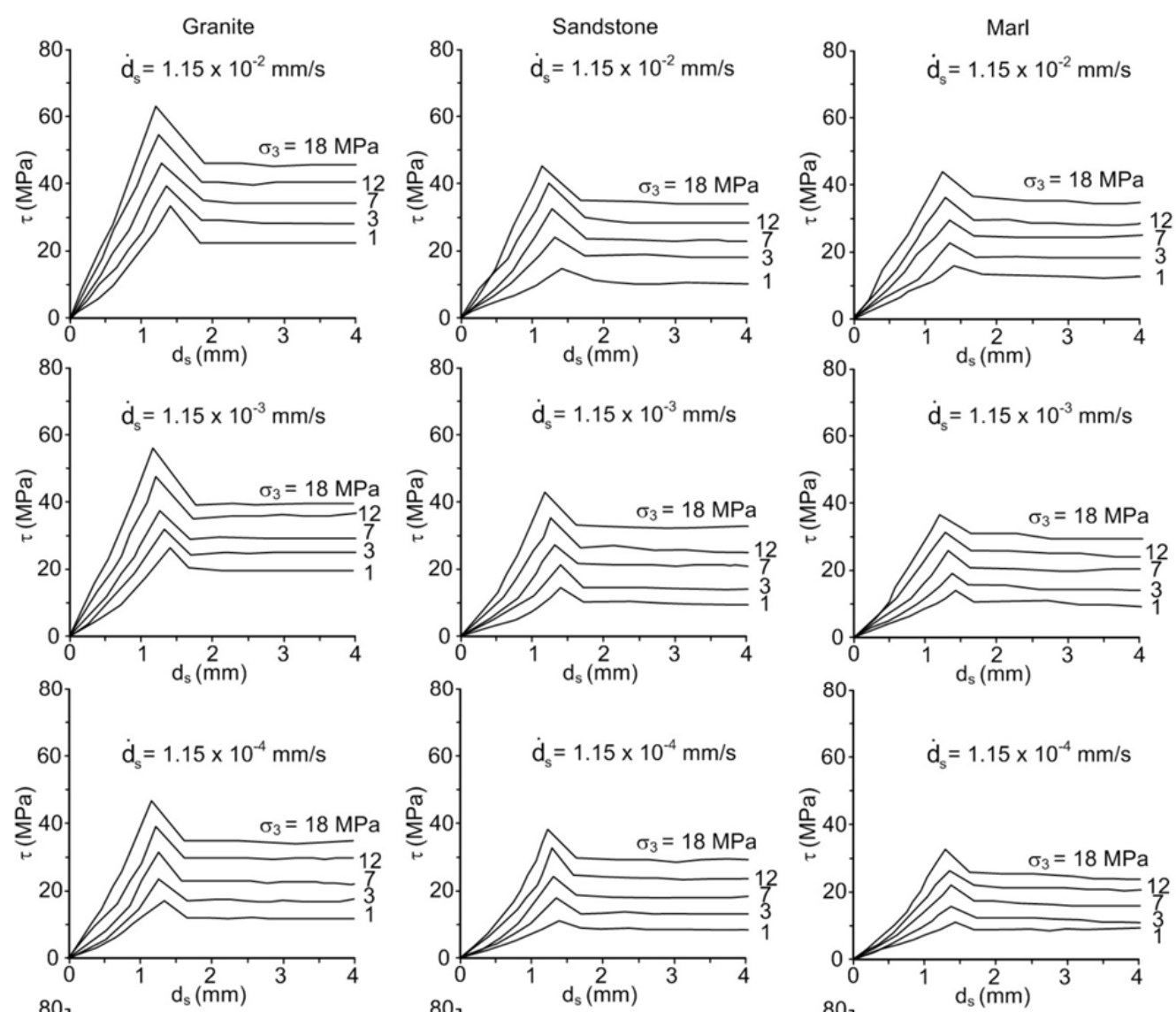

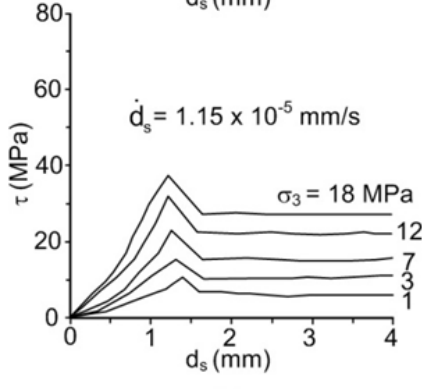

(a)

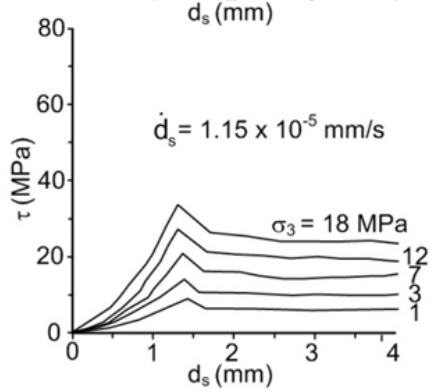

(b)

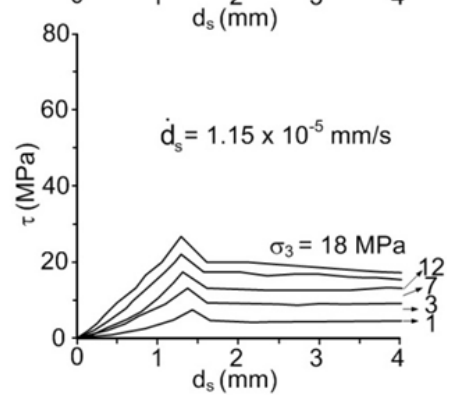

(c)

Figures 4. Shear stresses $(\tau)$ as a function of shear displacement $\left(\mathrm{d}_{\mathrm{s}}\right)$ for fractures in granite (a), sandstone (b) and $\operatorname{marl}(\mathrm{c})$

the test, implying that the fracture roughness remains relatively unchanged within the residual region. Larger confining pressures also induce lower fracture dilations. Granite with high strength and high JRC fractures tends to show larger dilations than do the lower strengths and lower JRC's sandstone and marl, particularly under low confining stresses. This is probably because the joint walls tend to climb over the asperities under low confining stresses while they tend to be sheared off under high confining stresses. This behavior can also be observed from the increase of dilation rates $\left(\mathrm{d}_{\mathrm{n}} / \mathrm{d}_{\mathrm{s}}\right)$ measured before the peak stresses, as shown in Figure 7. The diagrams show that the dilation rates also increase with the displacement velocity. Table 2 shows examples of some post-test fractures obtained under the highest and lowest displacement velocities and confining stresses for the three rock types. The light areas on the fracture surfaces represent the sheared-off asperities. The increase of confining 
stresses and the decrease of displacement velocities enhance the sheared-off areas. The scanning images of the post-test fractures show that the second order asperities are sheared-off for all tested rocks. The JRC's of the sheared fractures are determined from the laser scanning profile along the shear direction. Figure 8 plots the post-test JRC's as a function of $\sigma_{3}$. They support the previous observations that higher confining stresses and lower displacement velocities induce larger sheared-off areas, and result in a smoother fracture surface (lower JRC value).

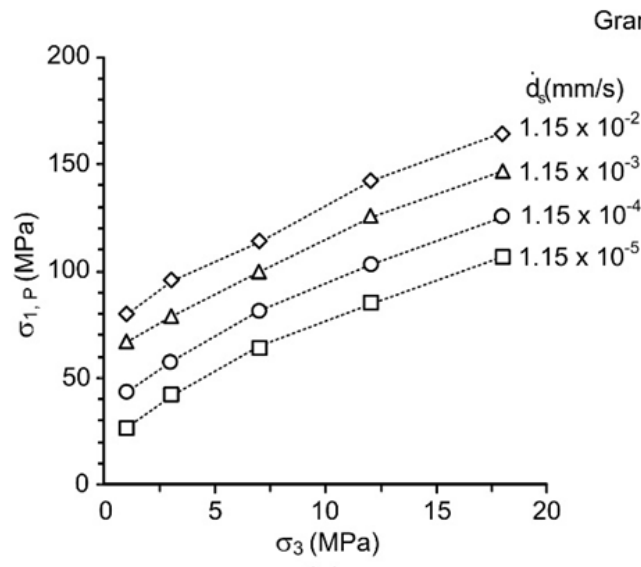

(a)

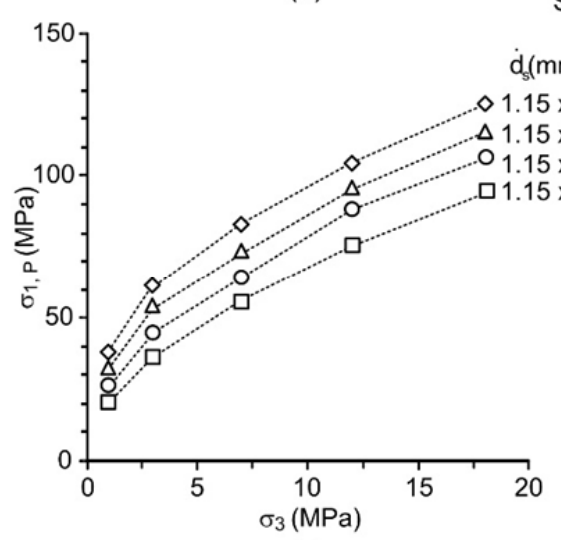

(c)

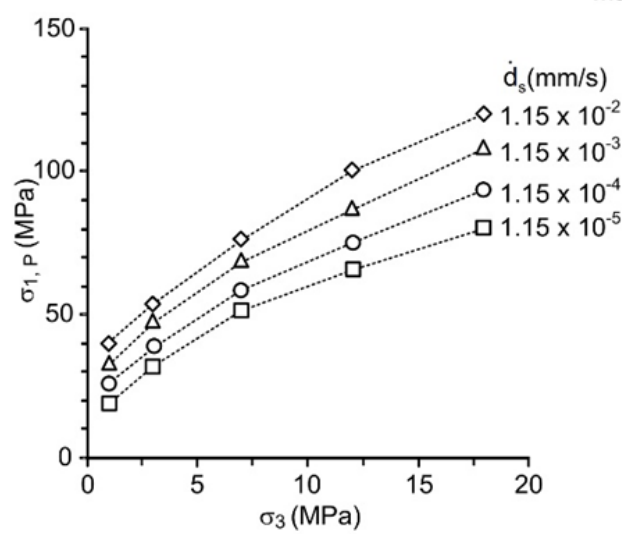

(e)
Sandstone

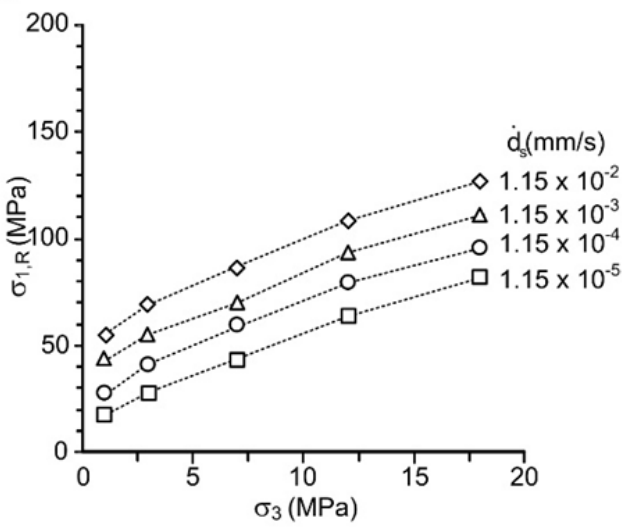

(b)

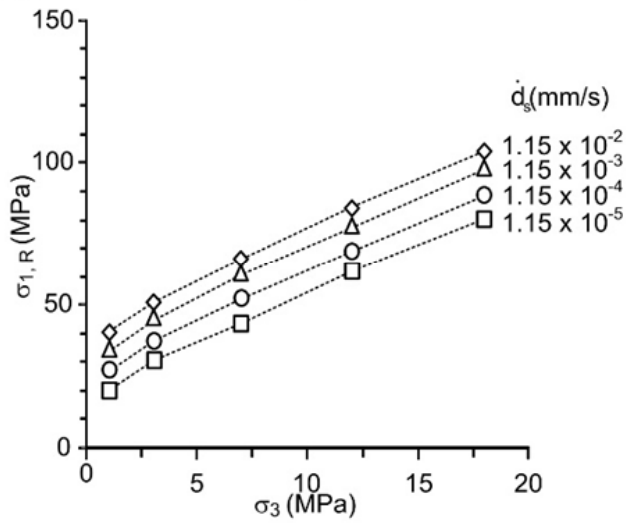

(d)

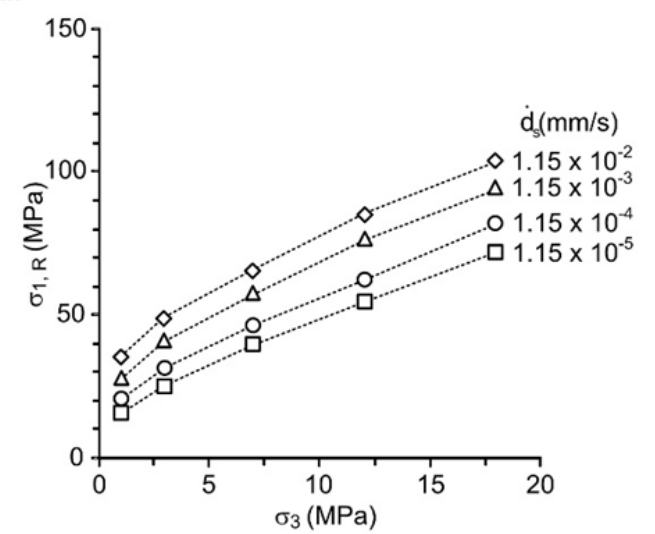

(f)

Figure 5. Major principal stresses at peak, $\sigma_{1, \mathrm{P}}(\mathrm{a}, \mathrm{c}, \mathrm{e})$ and at residual, $\sigma_{1, \mathrm{R}}(\mathrm{b}, \mathrm{d}, \mathrm{f})$ as a function of confining stresses $\left(\sigma_{3}\right)$ 


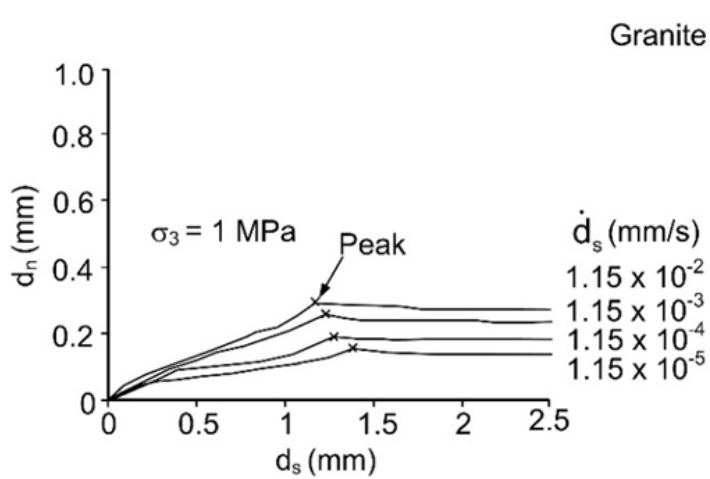

(a)

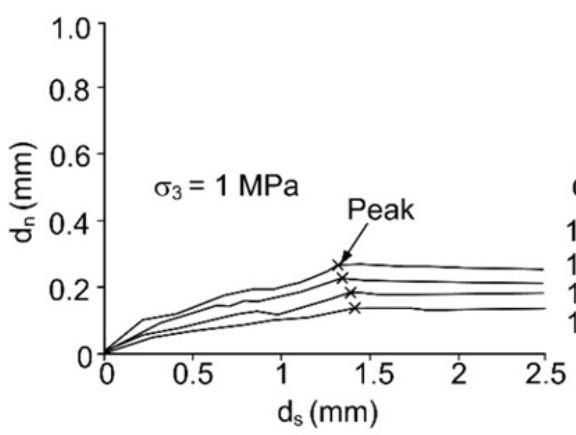

(c)

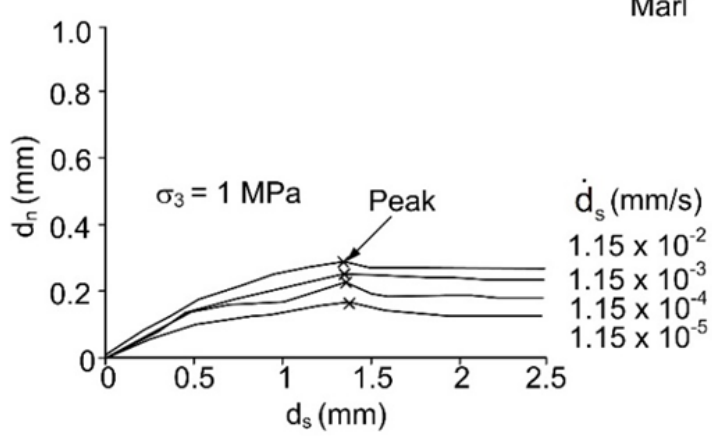

(e)

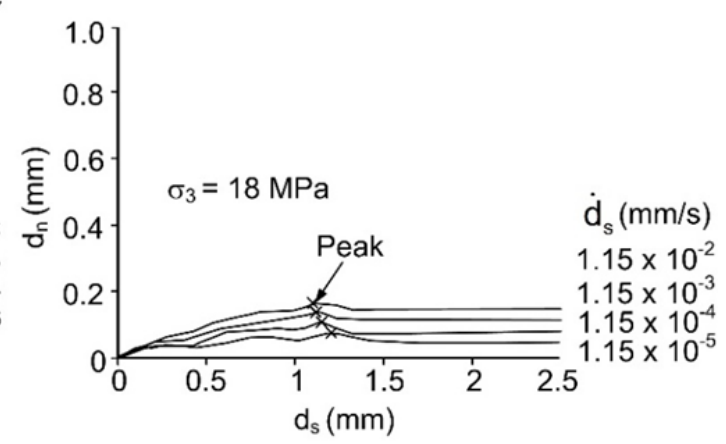

(b)

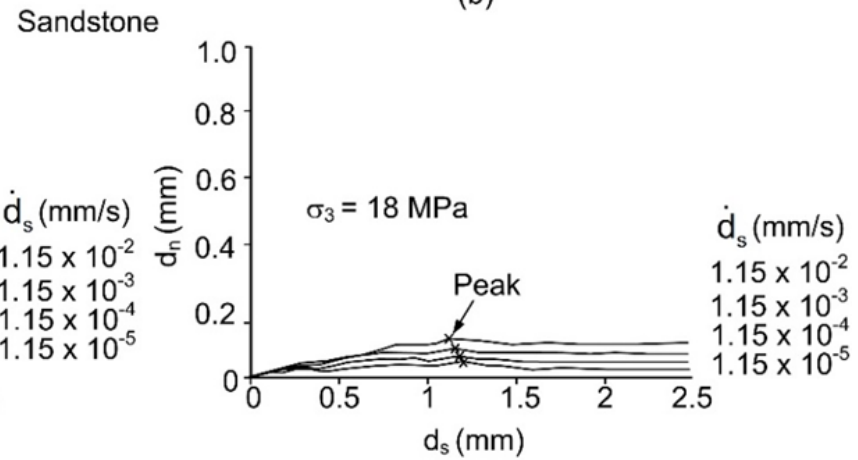

(d)

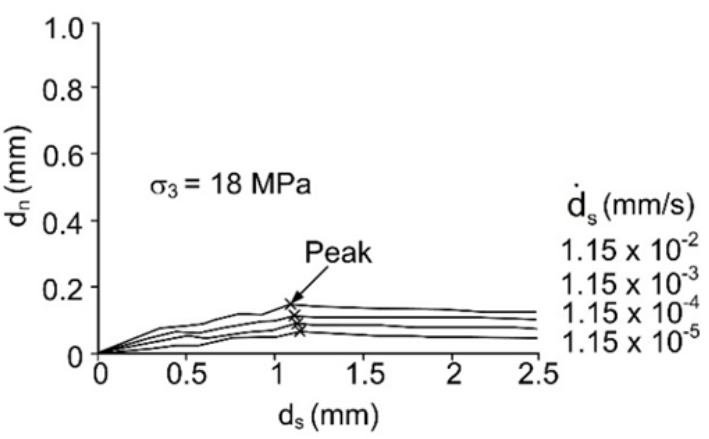

(f)

Figure 6. Normal displacement $\left(d_{n}\right)$ as a function of shear displacement $\left(d_{s}\right)$ for granite $(a, b)$, sandstone $(c, d)$ and marl $(e, f)$. The signs $(\times)$ represent the dilation corresponding to the peak strength

\section{Results of Smooth Saw-Cut Surfaces}

The shear strengths of smooth saw-cut surfaces are determined under the confining stresses between 1 and 12 MPa with displacement velocities from $1.15 \times 10^{-4}, 1.15 \times 10^{-3}$ to $1.15 \times 10^{-2} \mathrm{~mm} / \mathrm{s}$. The test procedure and calculation method are identical to those of the tension-induced fractures. The Coulomb criterion is applied to represent the peak shear strengths under various shear velocities and confinements:

$$
\tau=\sigma_{n} \cdot \tan (\phi)+c
$$

where $\phi$ and $\mathrm{c}$ are friction angle and cohesion of the saw-cut surfaces. The shear stress $(\tau)$ and normal stress $\left(\sigma_{\mathrm{n}}\right)$ are calculated from the major principal $\left(\sigma_{1}\right)$ and confining $\left(\sigma_{3}\right)$ stresses, using Equations (1) and $(2)$. The criterion is fitted to the test results in the forms of $\tau-\sigma_{\mathrm{n}}$ diagrams as shown in Figure 9. Good correlations $\left(\mathrm{R}^{2} \geq\right.$ $0.9)$ are obtained. The friction angles for granite, sandstone and marl are determined as $30^{\circ}, 33^{\circ}$ and $31^{\circ}$, and the cohesions are 1.36, 1.67 and 1.28 MPa, respectively. For all rock types the shearing resistances for the smooth saw-cut surfaces tend to be independent of the displacement velocity and confining stress. 




Figure 7. Dilation rates $\left(d_{n} / d_{s}\right)$ as a function of the shear velocity $\left(\dot{d}_{s}\right)$ for granite (a), sandstone (b) and marl (c)

Table 2. Some post-test fractures

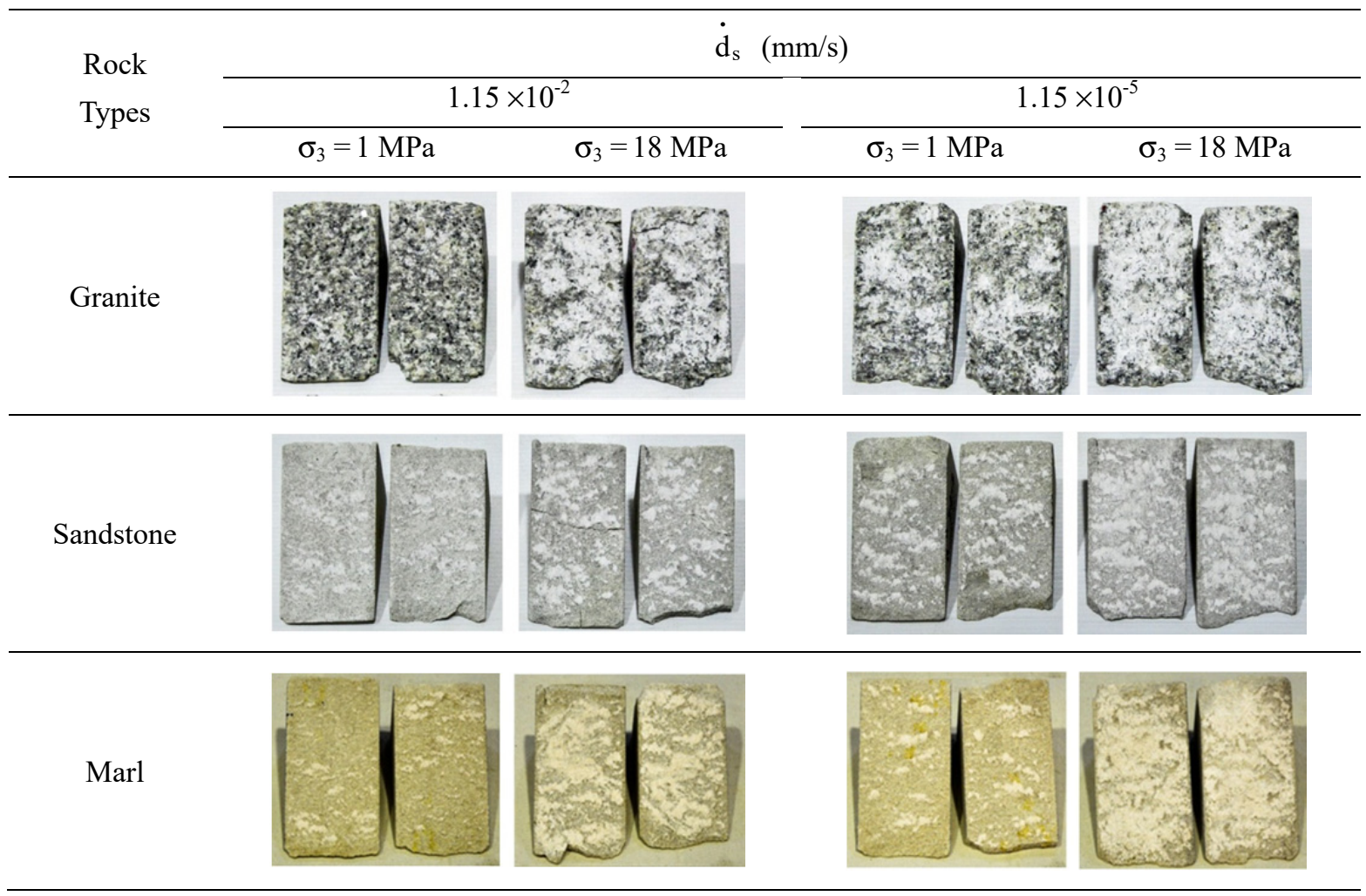




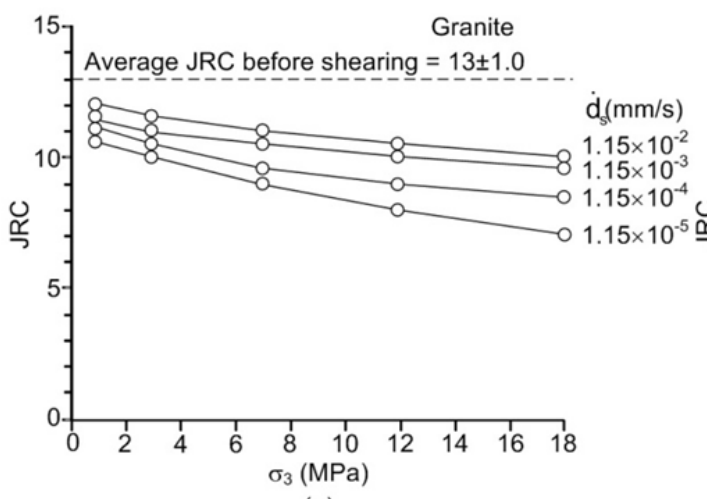

(a)

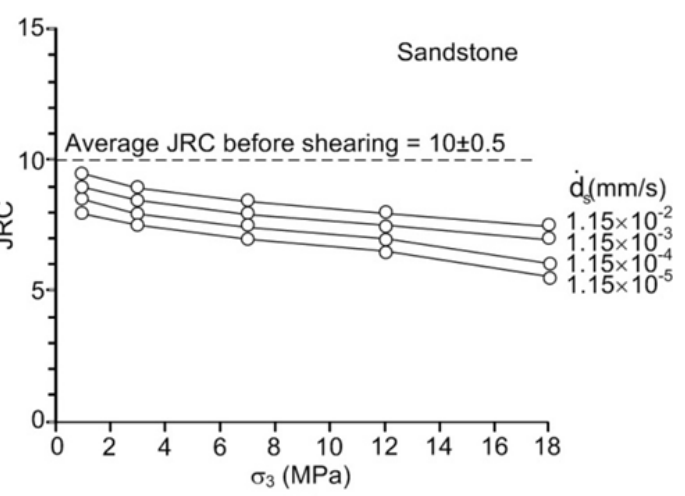

(b)

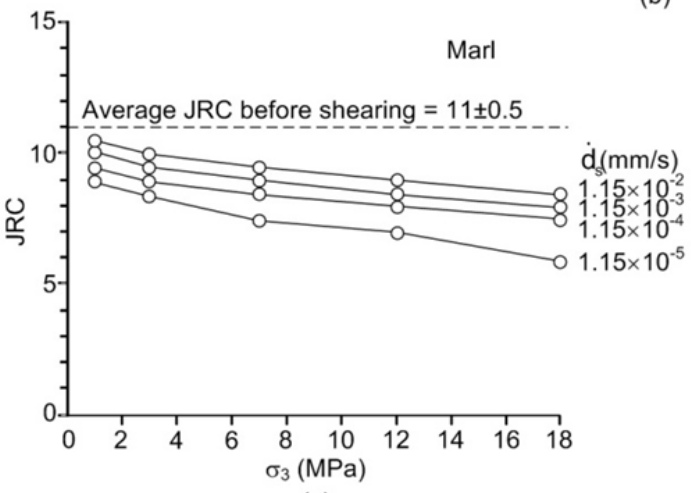

(c)

Figure 8. Post-test JRC's as a function of $\sigma_{3}$ for granite (a), sandstone (b), and marl (c)

\section{Empirical Criterion}

The empirical shear strength criterion for fractures under high confining pressures proposed by Barton (1976) and Barton \& Choubey (1977) can not be applied to the test results obtained here because as the confining stresses increase the $\tau-\sigma_{\mathrm{n}}$ relations for the three rock types tend to be non-linear. An alternative empirical criterion is proposed to represent the fracture shear strengths as a function of normal stress, as follows:

$$
\tau=\alpha \sigma_{n}^{\lambda}
$$

where $\alpha$ and $\lambda$ are empirical parameters, depending on rock types. Regression analyses are performed on Equation (7) using the peak and residual shear strength data given in Table 3 . Good correlations are obtained $\left(\mathrm{R}^{2}\right.$ $\geq 0.9$ ). The parameters $\alpha$ and $\lambda$ determined for each shear velocity are summarized in Table 4 . The parameter $\lambda$ tends to be independent of the shear velocity. It probably relates to the fracture roughness. This suggests by the fact that for each rock type $\lambda$ for residual shear strength is higher than that of the peak shear strength.(Table 4). For smooth saw-cut surface $\lambda$ would be equal to 1.0. The parameter $\alpha$ increases with shear velocity ( $\left.d_{s}\right)$, which can be best represented by:

$$
\alpha=\eta \dot{d}_{s} \omega
$$

where $\eta$ and $\omega$ are empirical constants. Their numerical values are given in Figure 10. For smooth saw-cut surface $(\lambda=1.0) \alpha$ is equal to tan $\phi_{b}$, and is independent of the shear velocity. This means that $\alpha$ is also dependent of fracture roughness, as evidenced by that $\alpha$ 's for the peak shear strengths are higher than those for the residual shear strengths. 



(b) Sandstone
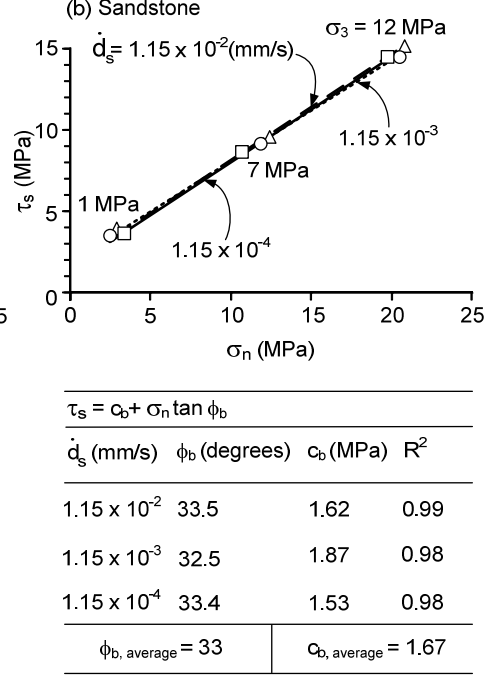

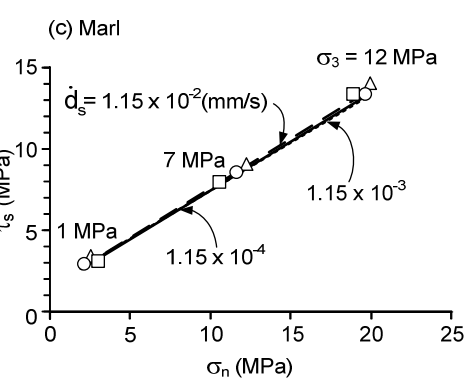

\begin{tabular}{|c|c|c|c|}
\hline \multicolumn{4}{|c|}{$\tau_{\mathrm{s}}=\sigma_{\mathrm{b}}+\sigma_{\mathrm{n}} \tan \phi_{\mathrm{b}}$} \\
\hline$\dot{\mathrm{d}}_{\mathrm{s}}(\mathrm{mm} / \mathrm{s})$ & $\phi_{\mathrm{b}}$ (degrees) & $\mathrm{C}_{\mathrm{b}}(\mathrm{MPa})$ & $\mathrm{R}^{2}$ \\
\hline $1.15 \times 10^{-2}$ & 31.5 & 1.26 & 0.98 \\
\hline $1.15 \times 10^{-3}$ & 31.7 & 1.31 & 0.98 \\
\hline $1.15 \times 10^{-4}$ & 31.0 & 1.28 & 0.98 \\
\hline$\phi_{\mathrm{b}, \text { aver }}$ & $g e=31$ & $\infty_{\infty}$, average $=$ & $=1.28$ \\
\hline
\end{tabular}

Figure 9. Shear strengths of smooth saw-cut surfaces in granite (a), sandstone (b) and marl (d)

Table 3. Peak and residual shear strengths and their corresponding normal stresses

\begin{tabular}{|c|c|c|c|c|c|c|c|c|c|c|c|c|c|}
\hline \multirow{2}{*}{$\begin{array}{l}\mathrm{d}_{\mathrm{s}} \\
(\mathrm{mm} / \mathrm{s})\end{array}$} & \multirow{2}{*}{$\begin{array}{l}\sigma_{3} \\
(\mathrm{MPa})\end{array}$} & \multicolumn{4}{|c|}{ Granite } & \multicolumn{4}{|c|}{ Sandstone } & \multicolumn{4}{|l|}{ Marl } \\
\hline & & $\begin{array}{l}\sigma_{\mathrm{n}} \\
(\mathrm{MPa})\end{array}$ & $\begin{array}{l}\tau_{\mathrm{r}} \\
(\mathrm{MPa})\end{array}$ & $\begin{array}{l}\sigma_{\mathrm{n}} \\
(\mathrm{MPa})\end{array}$ & $\begin{array}{l}\tau_{\mathrm{p}} \\
(\mathrm{MPa})\end{array}$ & $\begin{array}{l}\sigma_{\mathrm{n}} \\
(\mathrm{MPa})\end{array}$ & $\begin{array}{l}\tau_{\mathrm{r}} \\
(\mathrm{MPa})\end{array}$ & $\begin{array}{l}\sigma_{\mathrm{n}} \\
(\mathrm{MPa})\end{array}$ & $\begin{array}{c}\tau_{\mathrm{p}} \\
(\mathrm{MPa})\end{array}$ & $\begin{array}{l}\sigma_{\mathrm{n}} \\
(\mathrm{MPa})\end{array}$ & $\begin{array}{l}\tau_{\mathrm{r}} \\
(\mathrm{MPa})\end{array}$ & $\begin{array}{l}\sigma_{\mathrm{n}} \\
(\mathrm{MPa})\end{array}$ & $\tau_{\mathrm{p}}(\mathrm{MPa})$ \\
\hline \multirow[t]{5}{*}{$1.15 \times \mathbf{1 0}^{-2}$} & 1 & 14.4 & 22.5 & 20.6 & 33.9 & 10.5 & 13.4 & 10.2 & 15.9 & 9.1 & 14.0 & 10.6 & 16.7 \\
\hline & 3 & 20.4 & 29.1 & 26.0 & 39.8 & 14.8 & 20.4 & 17.4 & 24.9 & 14.4 & 19.7 & 15.7 & 22.1 \\
\hline & 7 & 27.8 & 34.8 & 33.8 & 46.3 & 21.7 & 25.5 & 25.7 & 32.4 & 22.2 & 26.2 & 24.5 & 30.3 \\
\hline & 12 & 37.3 & 42.3 & 44.4 & 56.1 & 30.1 & 31.3 & 35.0 & 39.8 & 30.1 & 31.3 & 34.1 & 38.3 \\
\hline & 18 & 46.5 & 47.6 & 54.5 & 63.2 & 39.6 & 37.5 & 44.9 & 46.6 & 39.6 & 37.5 & 43.7 & 44.4 \\
\hline \multirow[t]{5}{*}{$1.15 \times \mathbf{1 0}^{-3}$} & 1 & 13.0 & 20.0 & 17.2 & 28.1 & 9.0 & 10.9 & 8.9 & 13.8 & 7.3 & 11.0 & 8.9 & 13.8 \\
\hline & 3 & 16.6 & 22.6 & 21.9 & 32.8 & 13.5 & 18.3 & 15.6 & 21.8 & 12.3 & 16.0 & 14.1 & 19.1 \\
\hline & 7 & 23.4 & 27.3 & 29.8 & 39.5 & 20.5 & 23.3 & 23.6 & 28.8 & 20.1 & 22.6 & 22.4 & 26.6 \\
\hline & 12 & 33.4 & 35.7 & 40.2 & 48.8 & 28.5 & 28.6 & 33.0 & 36.4 & 28.0 & 27.7 & 30.8 & 32.5 \\
\hline & 18 & 42.2 & 40.4 & 50.1 & 55.6 & 38.0 & 34.6 & 42.4 & 42.2 & 37.1 & 33.1 & 40.4 & 38.7 \\
\hline \multirow[t]{5}{*}{$1.15 \times \mathbf{1 0}^{-4}$} & 1 & 8.5 & 12.5 & 11.3 & 17.9 & 7.4 & 9.1 & 7.3 & 10.8 & 5.6 & 7.9 & 7.3 & 11.0 \\
\hline & 3 & 13.4 & 17.4 & 16.8 & 23.9 & 11.5 & 14.6 & 13.6 & 18.4 & 10.0 & 12.2 & 12.1 & 15.8 \\
\hline & 7 & 21.1 & 23.6 & 25.5 & 32.0 & 18.4 & 19.7 & 21.5 & 25.2 & 16.8 & 16.9 & 19.9 & 22.4 \\
\hline & 12 & 29.9 & 29.9 & 35.1 & 40.1 & 26.3 & 24.8 & 30.8 & 32.6 & 24.6 & 21.9 & 27.8 & 27.4 \\
\hline & 18 & 38.8 & 34.7 & 45.2 & 47.1 & 35.8 & 30.8 & 40.1 & 38.2 & 34.2 & 28.0 & 36.9 & 32.8 \\
\hline \multirow[t]{5}{*}{$1.15 \times 10^{-5}$} & 1 & 5.1 & 6.9 & 7.1 & 10.6 & 5.6 & 7.9 & 6.0 & 8.7 & 4.5 & 6.1 & 5.6 & 7.9 \\
\hline & 3 & 9.7 & 11.1 & 13.0 & 17.4 & 9.8 & 11.7 & 11.7 & 15.1 & 8.5 & 9.5 & 10.3 & 12.6 \\
\hline & 7 & 16.7 & 16.3 & 21.3 & 24.7 & 16.3 & 16.1 & 19.4 & 21.5 & 15.3 & 14.3 & 18.2 & 19.3 \\
\hline & 12 & 25.8 & 23.0 & 30.5 & 32.0 & 24.5 & 21.7 & 28.3 & 28.3 & 22.8 & 18.7 & 25.5 & 23.3 \\
\hline & 18 & 35.0 & 28.4 & 40.2 & 38.5 & 33.7 & 27.3 & 37.4 & 33.5 & 31.6 & 23.6 & 33.6 & 27.0 \\
\hline
\end{tabular}

Table 4. Parameters $\alpha$ and $\lambda$ for peak and residual shear strengths

\begin{tabular}{|c|c|c|c|c|c|c|c|c|c|c|c|c|}
\hline \multirow{3}{*}{$\begin{array}{c}\mathrm{d}_{\mathrm{s}} \\
(\mathrm{mm} / \mathrm{s})\end{array}$} & \multicolumn{4}{|c|}{ Granite } & \multicolumn{4}{|c|}{ Sandstone } & \multicolumn{4}{|c|}{ Marl } \\
\hline & \multicolumn{2}{|c|}{ Peak } & \multicolumn{2}{|c|}{ Residual } & \multicolumn{2}{|c|}{ Peak } & \multicolumn{2}{|c|}{ Residual } & \multicolumn{2}{|c|}{ Peak } & \multicolumn{2}{|c|}{ Residual } \\
\hline & $\alpha$ & $\lambda$ & $\alpha$ & $\lambda$ & $\alpha$ & $\lambda$ & $\alpha$ & $\lambda$ & $\alpha$ & $\lambda$ & $\alpha$ & $\lambda$ \\
\hline $1.15 \times 10^{2}$ & 4.47 & 0.668 & 3.59 & 0.682 & 3.31 & 0.700 & 2.74 & 0.721 & 3.52 & 0.673 & 3.00 & 0.693 \\
\hline $1.15 \times 10^{3}$ & 4.04 & 0.668 & 3.21 & 0.682 & 3.10 & 0.700 & 2.54 & 0.721 & 3.20 & 0.673 & 2.69 & 0.693 \\
\hline $1.15 \times 10^{4}$ & 3.65 & 0.668 & 2.86 & 0.682 & 2.90 & 0.700 & 2.36 & 0.721 & 2.90 & 0.673 & 2.42 & 0.693 \\
\hline $1.15 \times 10^{5}$ & 3.30 & 0.668 & 2.55 & 0.682 & 2.71 & 0.700 & 2.18 & 0.721 & 2.63 & 0.673 & 2.17 & 0.693 \\
\hline
\end{tabular}



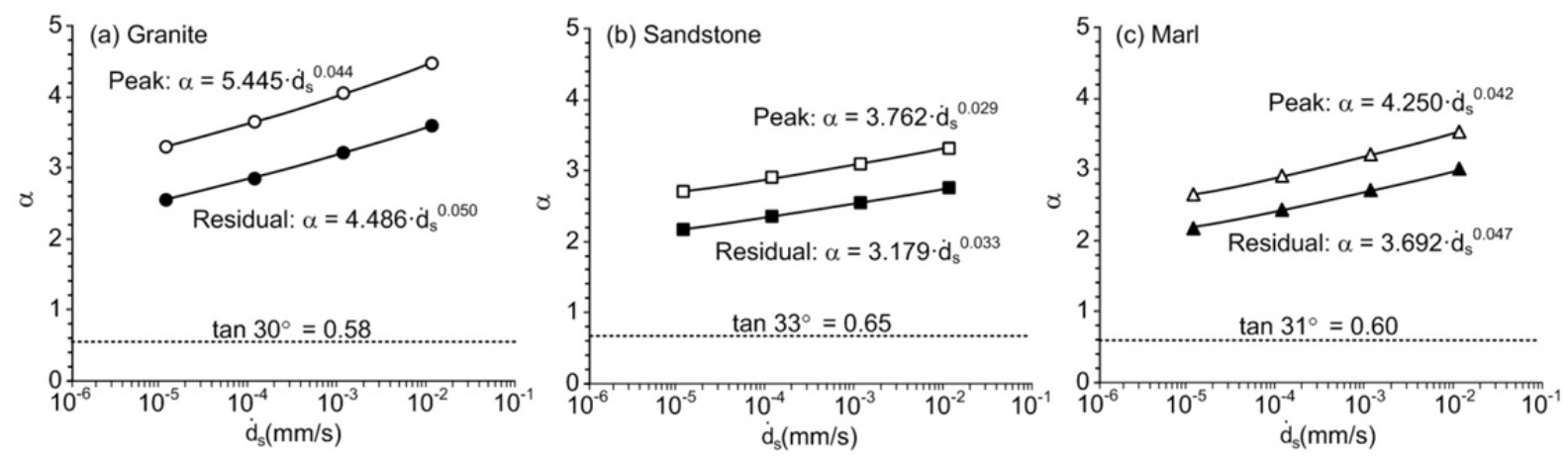

Figures 10. Parameter $\alpha$ as a function of shear velocity

Substituting Equation (8) into Equation (7) the fracture shear strength criterion that considers the shear velocity effect is obtained. Figure 11 compares the proposed criterion with the peak and residual shear strength results. The upper bound of the shear strengths is defined by the angle $\beta$ which is maintained constant at 59.1 degrees. The lower bound is defined by the basic friction angle $\left(\phi_{\mathrm{b}}\right)$ obtained from the smooth saw-cut surfaces testing.

\section{Discussions and conclusions}

The angle $\beta$ which is maintained constant at $59.1^{\circ}$ limits the lower ends of the $\tau-\sigma_{\mathrm{n}}$ curves for the peak and residual shear strengths (Figure 12). This angle is selected primarily because it gives the length-to-width ratio of the block specimens of about 2.0 which is most suitable for the polyaxial loading device. Different angles will provide different magnitudes of $\sigma_{1}$ and $\sigma_{3}$ that correspond to the same peak and residual shear strengths. As a result the fracture shear strengths obtained from the triaxial shear testing would be independent of this angle.

For all rock types the fracture dilations measured prior to and after the peak strengths significantly decrease with increasing confining pressures and decreasing displacement velocities (Figure 7). This is supported by the visual observations and the JRC measurements of the post-test fractures that the reduction of the shear velocity notably increases the sheared-off areas, particularly when the fractures are under high confining pressures (Table 2).

A quantitative assessment of the relations between the fracture roughness and the displacement velocity cannot be made. Only a narrow range of JRC's is obtained from the tension-inducing method for each rock type. Nevertheless, the granite with rougher fractures tends to show larger time-dependent effect than those obtained from the smoother fractures in sandstone and marl. This is also evidenced by the fact that for all rock types the shear strengths of smooth saw-cut surfaces are independent of the displacement velocity.

The velocity-dependent shear strengths can be observed more clearly in stronger granite than in the softer sandstone and marl (Figure 5). This agrees with the conclusions drawn by Crawford \& Curran (1981). The velocity-dependent strengths are probably governed by the time-dependent propagation of fissures and micro-cracks of rock forming minerals on the fracture wall. Each rock type may be sensitive to a certain range of the displacement velocities. The range of the displacement velocities used in this study $\left(1.15 \times 10^{-5}-1.15 \times 10^{-2}\right.$ $\mathrm{mm} / \mathrm{s}$ ) may reflect the time-dependent shear strengths of the granite fractures better than those of the sandstone and marl fractures. The time-dependent shear strength of fractures in sandstone and marl would be more clearly observed if a higher range of displacement velocities was used (i.e., higher than $10^{-2} \mathrm{~mm} / \mathrm{s}$ ).

The fracture areas tested here $\left(50 \times 100 \mathrm{~mm}^{2}\right)$ are relatively small even though they comply with the ASTM standard practice and ISRM suggested method. Barton \& Bandis (1980), Fardin et al. (2001), Ohnaka (2003), and Johansson \& Stille (2014) conclude from their experimental and observational results that fracture shear strengths decrease with increasing scale. As a result the shear strengths obtained here would likely overestimate those of the larger fractures under in-situ condition.

The triaxial shear testing has clear advantages over the direct shear testing. It allows simulating the shearing resistances of fractures under significantly larger confining pressures and normal stresses than those of the direct shear test where it is limited by the unconfined compressive strength of the rock. The triaxial test configurations and loading paths would be similar to those of the in-situ conditions where $\sigma_{1}$ that induces relative displacement is mostly not parallel to the fracture or fault planes. As a result a constitutive law and model describing fracture shear strengths and dilations under triaxial stress states, such as the one proposed in this study, would likely represent the shearing behavior of in-situ fractures or faults at great depths better than that obtained under low normal stresses and unconfined conditions. 

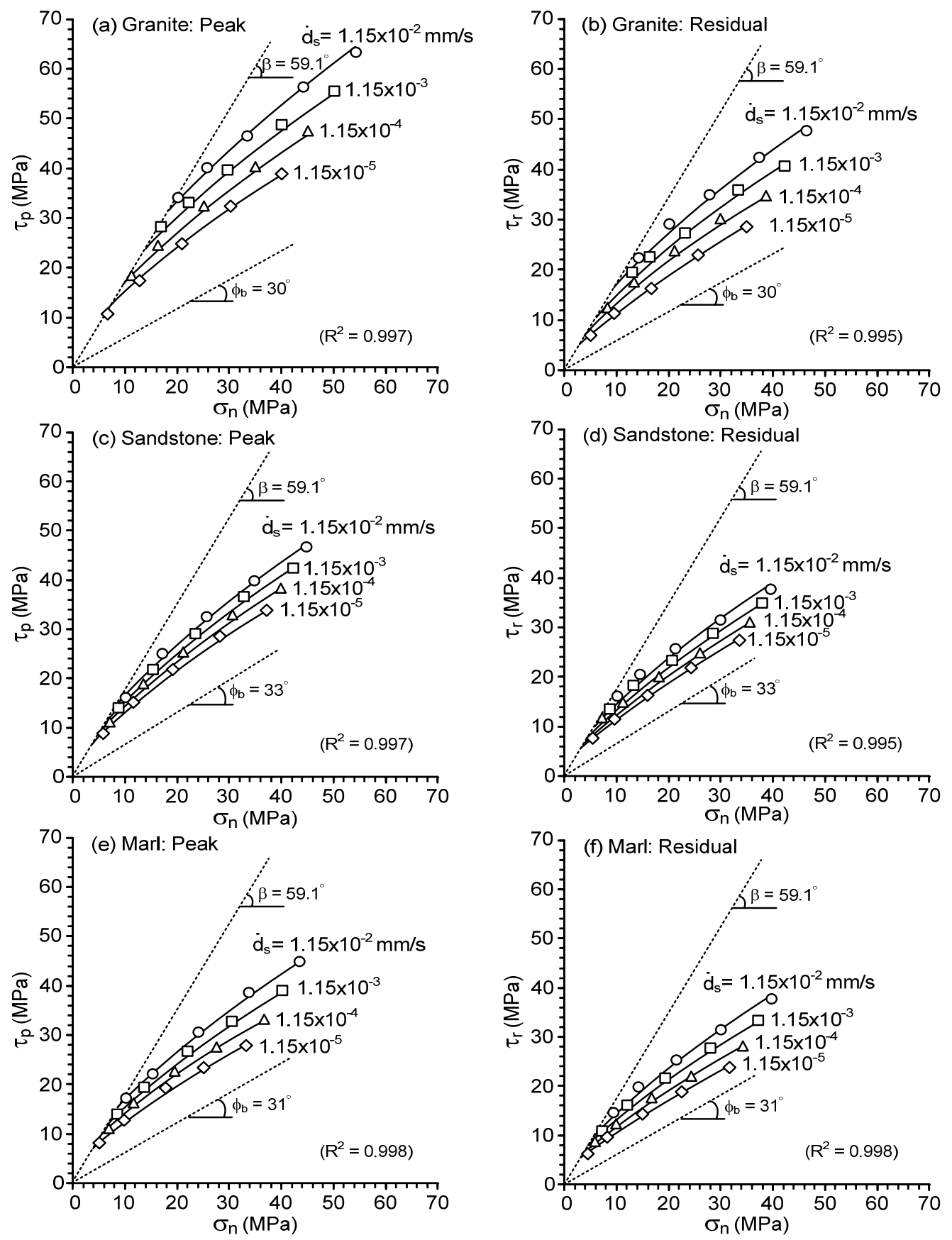

Figures 11. Proposed empirical criterion for peak and residual shear strengths compared with test data for granite $(a, b)$, sandstone $(c, d)$ and marl $(e, f)$

\section{Acknowledgments}

This study is funded by Suranaree University of Technology and by the Higher Education Promotion and National Research University of Thailand. Permission to publish this paper is gratefully acknowledged.

\section{References}

Asadollahi, A., \& Tonon, F. (2010). Constitutive model for rock fractures: Revisiting Barton's empirical model. Engineering Geology, 113(1-4), 11-32. http://dx.doi.org/10.1016/j.enggeo.2010.01.007

ASTM D5607-08. (1995). Standard test method for performing laboratory direct shear strength tests of rock specimens under constant normal force. Annual Book of ASTM Standards. (Vol. 04.08), West Conshohocken, 
PA: American Society for Testing and Materials. http://dx.doi.org/ 10.1520/D5607-95

ASTM D7012-07. (2007). Standard Test Method for compressive strength and elastic moduli of intact rock core specimens under varying states of stress and temperatures. Annual Book of ASTM Standards (Vol. 04.08), Philadelphia: American Society for Testing and Materials. http://dx.doi.org/ 10.1520/D7012-07

Bandis, S., Lumsden, A. C., \& Barton, N. R. (1981). Experimental studies of scale effects on the shear behaviour of rock joints. International Journal of Rock Mechanics and Mining Sciences \& Geomechanics Abstracts, 18(1), 1-21. http://dx.doi.org/10.1016/0148-9062(81)90262-X

Barton, N. (1976). The shear strength of rock and rock joint. International Journal of Rock Mechanics and $\begin{array}{lllll}\text { Mining Sciences \& } \quad \text { Geomechanics } & \text { Abstracts, }\end{array}$ http://dx.doi.org/10.1016/0148-9062(76)90003-6

Barton, N. (1982). Characterizing rock masses to improve excavation design. Panel Report, Theme II Tunnelling and Excavation. Proceeding of 4th Congress international association for engineering geology and the environment, New Delhi.

Barton, N. (2013). Shear strength criteria for rock, rock joints, rockfill and rock masses: Problems and some solutions. Journal of Rock Mechanics and Geotechnical Engineering, 5(4), 249-261. http://dx.doi.org/10.1016/j.jrmge.2013.05.008

Barton, N., \& Bandis, S. (1980). Some effects of scale on the shear strength of joints. International Journal of Rock Mechanics and Mining Sciences \& Geomechanics Abstracts, 17(1), 69-73. http://dx.doi.org/10.1016/0148-9062(80)90009-1

Barton, N., \& Choubey, V. (1977). The shear strength of rock joints in theory and practice. International Journal of Rock Mechanics and Mining Sciences \& Geomechanics Abstracts, 10(1-2), 1-54. http://dx.doi.org/10.1007/BF01261801

Belem, T., Homand-Etienne, F., \& Souley, M. (2000). Quantitative parameters for rock joint surface roughness. Rock mechanics and rock Engineering, 33(4), 217-242. http://dx.doi.org/10.1007/s006030070001

Boonsener, M., \& Sonpiron, K. (1997). Correlation of tertiary rocks in northeast, Thailand. Proceeding of International Conference on Stratigraphy and Tectonic Evolution of Southeast Asia and the South Pacific (pp. 656-661). Bangkok, Thailand.

Brady, B. H. G., \& Brown, E. T. (2006). Rock Mechanics for Underground Mining (3 ${ }^{\text {rd }}$ ed.). Dordrecht, Netherlands: Springer.

Brown, E. T. (1981). Rock Characterization Testing and Monitoring: ISRM Suggested methods. The Commission on Rock Testing Methods, International Society for Rock Mechanics, Pergamon Press, New York.

Bunopas, S. (1992). Regional stratigraphic correlation in Thailand. Proceeding of National Conference on Geological Resources of Thailand: Potential for Future Development, Department of mineral Resources, Bangkok, Thailand.

Choi, S. O., \& Chung, S. K. (2004). Stability analysis of jointed rock slopes with the Barton-Bandis constitutive model in UDEC. International Journal of Rock Mechanics and Mining Sciences, 41(3), 581-586. http://dx.doi.org/10.1016/j.ijrmms.2004.03.103

Crawford, A. M., \& Currant, J. H. (1981). The influence of shear velocity on the frictional resistance of rock discontinuities. International Journal of Rock Mechanics and Mining Sciences \& Geomechanics Abstracts, 18(6), 505-515. http://dx.doi.org/10.1016/0148-9062(81)90514-3

Curran, J. H., \& Leong, P. K. (1983). Influence of shear velocity on rock joint strength. Proceeding of 5th ISRM Congress (pp. A235-A240). International Society for Rock Mechanics, Melbourne, Australia.

Fardin, N., Stephansson, O., \& Jing, L. (2001). The scale dependence of rock joint surface roughness. International Journal of Rock Mechanics and Mining Sciences, 38(5), 659-669. http://dx.doi.org/10.1016/S1365-1609(01)00028-4

Fenton, C. H., Charusiri, P., \& Wood, S. H. (2003). Recent paleoseismic investigations in Northern and Western Thailand. Annals of Geophysics, 46(5), 957-981. http:// dx.doi.org/10.4401/ag-3464

Fuenkajorn, K., \& Kenkhunthod, N. (2010). Influence of loading rate on deformability and compressive strength of three Thai sandstones. Geotechnical and Geological Engineering, 28(5), 707-715. http://dx.doi.org/10.1007/s10706-010-9331-7 
Grasselli, G., \& Egger, P. (2003). Constitutive law for the shear strength of rock joints based on three-dimensional surface parameters. International Journal of Rock Mechanics and Mining Sciences, 40(1), 25-40. http://dx.doi.org/10.1016/S1365-1609(02)00101-6

Hong, E. S., Lee, I. M., Cho, G. C., \& Lee, S. W. (2014). New approach to quantifying rock joint roughness based on roughness mobilization characteristics. KSCE Journal of Civil Engineering, 18(4), 984-991. http://dx.doi.org/10.1007/s12205-014-0333-5

Jaeger, J. C., Cook, N. G. W., \& Zimmerman, R. W. (2007). Fundamentals of Rock Mechanics (4th ed.). Malden: Blackwell Publishing.

Jafari, M. K., Hosseini, K. A., Pellet, F., \& Boulon, M. (2003). Evaluation of shear strength of rock joints subjected to cyclic loading. Soil Dynamics and Earthquake Engineering, 23(7), 619-630. http://dx.doi.org/10.1016/S0267-7261(03)00063-0

Jang, H. S., \& Jang, B. A. (2015). New Method for Shear Strength Determination of Unfilled, Unweathered Rock Joint. Rock Mechanics and Rock Engineering, 48(4), 1515-1534. http://dx.doi.org/10.1007/s00603-014-0660-3

Johansson, F., \& Stille, H. (2014). A conceptual model for the peak shear strength of fresh and unweathered rock joints. International Journal of Rock Mechanics and Mining Sciences, 69, 31-38. http://dx.doi.org/10.1016/j.ijrmms.2014.03.005

Kamonphet, T., Khamrat, S., \& Fuenkajorn, K. (2015). Effects of cyclic shear loads on strength, stiffness and dilation of rock fractures. Songklanakarin Journal of Science and Technology, 37(6), 683-690.

Kapang, P., Walsri, C., Sriapai, T., \& Fuenkajorn, K. (2013). Shear strengths of sandstone fractures under true triaxial stresses. Journal of Structural Geology, 48, 57-71. http://dx.doi.org/10.1016/j.jsg.2012.12.007

Lee, H. S., Park, Y. J., Cho, T. F., \& You, K. H. (2001). Influence of asperity degradation on the mechanical behavior of rough rock joints under cyclic shear loading. International Journal of Rock Mechanics and Mining Sciences, 38(7), 967-980. http://dx.doi.org/10.1016/S1365-1609(01)00060-0

Lee, Y. H., Carr, J. R., Barr, D. J., \& Haas, C. J. (1990). The fractal dimension as a measure of the roughness of rock discontinuity profiles. International Journal of Rock Mechanics and Mining Sciences \& Geomechanics Abstracts, 27(6), 453-464. http://dx.doi.org/10.1016/0148-9062(90)90998-H

Li, B., Jiang, Y., \& Wang, G. (2012). Evaluation of shear velocity dependency of rock fractures by using repeated shear tests. Proceeding of 12th ISRM Congress, Harmonising Rock Engineering and the Environment (pp. 699-702). Beijing, China. http://dx.doi.org/10.1201/b11646-125

Li, Y., \& Zhang, Y. (2015). Quantitative estimation of joint roughness coefficient using statistical parameters. International Journal of Rock Mechanics and Mining Sciences, 77, 27-35. http://dx.doi.org/10.1016/j.jirmms.2015.03.016

Li, Y., Wang, J., Jung, W., \& Ghassemi, A. (2012). Mechanical properties of intact rock and fracture in welded tuff from newberry volcano. Proceeding of Thirty-Seventh Workshop on Geothermal Reservoir Engineering Stanford University. Standford, California.

Lockner, D. A., Summers, R., \& Byerlee, J. D. (1986). Effects of temperature and sliding rate on frictional strength of granite. Pure and applied geophysics, 124(3), 445-469. http://dx.doi.org/10.1007/BF00877211

Mahawat, C., Atherton, M. P., \& Brotherton, M. S. (1990). The Tak Batholith, Thailand: the evolution of contrasting granite types and implications for tectonic setting. Journal of Southeast Asian Earth Sciences, 4(1), 11-27. http://dx.doi.org/10.1016/0743-9547(90)90021-5

Mitchell, E. K., Fialko, Y., \& Brown, K. M. (2013). Temperature dependence of frictional healing of Westerly granite: Experimental observations and numerical simulations. Geochemistry, Geophysics, Geosystems, 14(3), 456-582. http://dx.doi.org/10.1029/2012GC004241

Nilsen, B. (2000). New trends in rock slope stability analyses. Bulletin of Engineering Geology and the Environment, 58, 173-178. http://dx.doi.org/10.1007/s100640050072

Odling, N. E. (1994). Natural fracture profiles, fractal dimension and joint roughness coefficients. Rock Mechanics and Rock Engineering, 27(3), 135-153. http://dx.doi.org/10.1007/BF01020307

Ohnaka, M. (2003). A constitutive scaling law and a unified comprehension for frictional slip failure, shear fracture of intact rock, and earthquake rupture. Journal of Geophysical Research, 108(B2, 2080), 6-1-6-12. 
http://dx.doi.org/10.1029/2000JB000123

Rafek, A. G., \& Goh, T. L. (2012). Correlation of joint roughness coefficient (JRC) and peak friction angles of discontinuities of Malaysian Schists. Earth Science Research, 1(1), 57-63. http://dx.doi.org/10.5539/esr.v1n1p57

Shrivastava, A. K., \& Rao, K. S. (2015). Shear behaviour of rock joints under CNL and CNS boundary conditions. Geotechnical and Geological Engineering, 33, 1205-1220. http://dx.doi.org/10.1007/s10706-015-9896-2

Stesky, R. M. (1978). Rock friction-effect of confining pressure, temperature, and pore pressure. pure and applied geophysics, 116(4), 690-704. http://dx.doi.org/10.1007/BF00876532

Stesky, R. M., Brace, W. F., Riley, D. K., \& Robin, P. Y. F. (1974). Friction in faulted rock at high temperature and pressure. Tectonophysics, 23(1-2), 177-203. http://dx.doi.org/10.1016/0040-1951(74)90119-X

Tang, H., Ge, Y., Wang, L., Yuan, Y., \& Huang, L. (2012). Study on estimation method of rock mass discontinuity shear strength based on three-dimensional laser scanning and image technique. Journal of Earth Science, 23(6), 908-913. http://dx.doi.org/10.1007/s12583-012-0301-2

Usefzadeh, A. (2013). Empirical and mathematical formulation of the shear behavior of rock joints. Engineering Geology, 164(17), 243-252. http://dx.doi.org/10.1016/j.enggeo.2013.07.013

Wang, M., Cao, P., \& Li, R. (2015). Joint roughness coefficient and fractal dimension calculation for rock profile and their empirical formula. Electronic Journal of Geotechnical Engineering, 20, 12103-12111.

Yeo, I. W., De Freitas, M. H., \& Zimmerman, R. W. (1998). Effect of shear displacement on the aperture and permeability of a rock fracture. International Journal of Rock Mechanics and Mining Sciences, 35(8), 1051-1070. http://dx.doi.org/10.1016/S0148-9062(98)00165-X

\section{Copyrights}

Copyright for this article is retained by the author(s), with first publication rights granted to the journal.

This is an open-access article distributed under the terms and conditions of the Creative Commons Attribution license (http://creativecommons.org/licenses/by/3.0/). 